\title{
Application of Financial Engineering Instruments in the Russian Automotive Industry
}

\author{
Ajupov A. A. ${ }^{1}$, Kurilova A. A. ${ }^{2} \&$ Ivanov D. U. ${ }^{3}$ \\ ${ }^{1}$ Kazan Federal University, Institute of Management, Economics and Finance, Kazan, Russia \\ ${ }^{2}$ Togliatti State University, Togliatti, Russia \\ ${ }^{3}$ Samara State Aerospace University, Samara, Russia \\ Correspondence: Kurilova A. A., Togliatti State University, Togliatti, 445667, Russia. Tel: 79-17-122-3879. \\ E-mail: aakurilova@yandex.ru
}

Received: March 10, 2015 Accepted: March 31, 2015 Online Published: April 30, 2015

doi:10.5539/ass.v11n11p162 URL: http://dx.doi.org/10.5539/ass.v11n11p162

\begin{abstract}
The problem of the reducing the financial risks faced by any company in the market economy. The automotive industry is also sensitive to currency and commodity risks. The article presents the economic and mathematical model of the creation of option portfolios in the automotive industry, which allows to develop investment and speculative strategies in the stock market, as well as the methods of hedging currency risks in the automotive industry, depending on the net position.
\end{abstract}

Keywords: options, automotive industry, risk, futures, foreign exchange risks, steel, a model

\section{Introduction}

In world practice, the use of various financial instruments hedging has long been an integral part of the economic activity of the largest companies.

Initially, risk management applied at the unit level corporations and the main task was to reduce the costs incurred by currency fluctuations. Today, the corporation is carried out both short and long-term currency risk management across the organization, using financial and non-financial hedging strategies. In this case, the main task is considered, on the one hand, the reduction of risks from adverse changes in exchange rates, and on the other - to benefit from favorable changes.

Under the derivatives are understood financial contracts with standard terms and conditions agreed by the parties or the value of which is a derivative with respect to the underlying asset.

\section{Theory}

Futures and options are the most common hedging instruments.

The advantages of using futures are:

- The availability of an organized market - access to the stock market is real for a small company or a private investor, while OTC transactions are with professional financial market participants and the effectiveness of these transactions depends on the size and reputation of the organization;

- To conduct hedging without taking significant credit risk - the main credit risk is the risk in the hedge of the exchange, which is usually significantly lower than the counterparty credit risk in the OTC market; credit risk is reduced through effective mechanisms for offsetting requirements are usually proposed by the Exchange;

- Ease of adjusting the hedging position or closing it;

- Availability of statistics on prices and trading volumes on the available tools that allows you to choose the optimal hedging strategy.

The disadvantages of this type of hedging are:

- Inability to use fixed-term contracts of any size, and the period of performance - standard contracts involve fixed lot size and duration, a lot of them is limited, because of this basis risk hedging is obviously impossible to make less than a certain value; 
- The need for commission expenses in transactions;

- The need to divert resources and the adoption of liquidity risk in the implementation of hedging - the sale and purchase of standard contracts require any deposit margin and its subsequent increase in the event of adverse price changes - for volatile instruments and long hedging volume of collateral (margin) may be significant.

The main feature of futures trading - fictitious transactions in which the sale takes place, but exchange of goods is almost completely absent (real asset supply end only $2 \%$ of the total number of transactions).

Terms of futures trading suggest the following: if the futures contract was originally sold (sell position is opened), then later it will be necessary to buy an identical futures contract (for the same asset in the same amount), i.e. Closed position. If was originally bought a futures contract (open Buy position), then to close the position it needs to sell. Uncovered by the due date of the transaction party positions will need to be put (take) the asset in its entirety.

Option - a contract in which the seller, for a fee, called a premium, gives the buyer the right to buy or sell an asset, the underlying, within a certain time at a predetermined price.

As an asset may be: futures, options, currency, securities, stock indexes, interest rates.

Costs for the purchase of the option are paid a premium. Additional collateral in the form of margin is required.

Distinguish option to buy (call) and an option to sell (put). In the first case, the buyer of an option acquires the right, but not the obligation to buy an asset exchange. In the second case, the buyer has the right but not the obligation to sell the asset.

In case of unfavorable price changes, the option buyer waives its right to buy (sell) an asset, the underlying. Thus, the maximum loss to the buyer of the option - the amount of the premium paid, and the profit potential is unlimited.

Compared with futures options are less costly and risky. Futures are desirable to use when there is confidence in the predictions of the future developments in the market. However, the conditions of this contract require that the transaction is executed and erroneous predictions may be lost. Therefore, to limit the risk of a certain amount of hedging, it is better to use options.

The main drawback of a simple option "call", which makes it difficult to use for the purpose of hedging - the high cost to the buyer. So simple monthly option "call" dollar / euro at the money («in the money" that is redeemable at a profit) in the average cost of 1 to $2 \%$ of the hedged amount. Longer options are even more expensive.

Despite the costs associated with hedging, and the numerous difficulties that the company may face in developing and implementing a hedging strategy, its role in ensuring sustainable development is large enough:

- a significant reduction in the price risk associated with the purchase of raw materials and delivery of finished products;

- hedging frees up resources of the company and helps management personnel to focus on core aspects of the business while minimizing risks, as well as increasing capital, reducing the cost of the use of funds and stabilizing incomes;

- the hedge does not meet with the usual business transactions and ensures continuous protection without the need to change the policy reserves or make long-term forward contracts;

- In many cases, hedge facilitates attraction of credit resources: banks take into account hedged deposits at a higher rate; the same applies to contracts for the supply of finished products.

\section{Results}

In the course of its business in the automotive industry there are two main types of risks.

The first type of risk associated with the possibility of increased cost of raw materials and components used in the production of motor vehicles, with the automotive industry, the company cannot raise the price of the final product due to high competition.

Valuation of the risk of increased prices of raw materials can be expressed as the following formula (1):

$$
\mathrm{P}=V * a(1)
$$

where:

$\mathrm{P}$ - valuation of risk; 
$V$ - conditionally - the valuation of the cost of the enterprise associated with the use of a particular type of raw material, including the component parts (e.g. steel) in the production of motor vehicles;

$a$ - possible increase in raw material costs, expressed as a decimal fraction, which can be determined on the basis of data on the average increase in the value of raw materials for the previous periods.

Making the decision to hedge the risk of possible when the valuation of risk above the cost of hedging (2).

$$
\mathrm{P}>C,(2)
$$

where:

$\mathrm{P}$ - valuation of risk;

$\mathrm{C}$ - the cost of hedging, defined as the value of the use of financial instruments.

The largest share in the automotive sector is steel - from 70 to $80 \%$ by weight of the domestic car. At the same time steel prices are highly volatile, which may lead to lower profits in the automotive industry.

Therefore, for the majority of the automotive industry is a relevant hedging increase in steel prices.

Available instruments hedge the rising cost of steel are futures and options on futures contracts that are traded on the London Metal Exchange. In terms of limiting the risk of potential losses on hedging operations are the most preferred option contracts, the risk of loss for which the premium is limited.

The second type of risk associated with the prisoners now the automotive industry export-import contracts and loan agreements, material terms of which are denominated in foreign currencies.

To determine the value of risk assessment is necessary to determine the net position of the company for each foreign currency on the following proposed formula (3).

$$
N_{\text {cur }}=\sum P V\left(E X_{t(\text { cur })}\right)-\sum P V\left(I M T_{t(\text { cur })}\right)
$$

$N_{c u r}$ - net position of the enterprise in a particular foreign currency CUR;

$E X_{t(\text { cur })}$ - the amount of the export contract with expiry date $t$, expressed in the currency of CUR, $I M T_{t(\text { cur })}$ - the amount of the export contract with the date t, expressed in the currency of CUR,

$$
\begin{gathered}
P V\left(E X_{t(\text { cur })}\right)=\mathrm{EX} /(1+\mathrm{r} / 12) 12 * \mathrm{n}, \\
P V\left(I M T_{t(\text { cur })}\right)=\mathrm{IMP} /(1+\mathrm{r} / 12) 12 * \mathrm{n},
\end{gathered}
$$

$r$ - the discount rate, it is proposed to take $r$ as equal to the LIBOR rate for a particular foreign currency,

$n$ - number of years before the date of expiry of the contract, expressed as an integer or a decimal fraction.

If the net position $(\mathrm{N})$ is equal to 0 , the risk positions in a particular currency CUR the enterprise are not currently available.

When the net position (N) is greater than 0 , the company bears the risk of appreciation (increase) the value of the national currency and the risk of reducing the value of the currency of the contract.

If the net position $(\mathrm{N})$ is less than 0 , the company bears the risk of reduction in price (reduction) of the national currency and the risk of rising value of the currency of the contract.

Valuation risk, if the net position is different from 0 , it is proposed to carry out on the basis of the estimated data on changes in the value of foreign currency by a formula similar to the valuation of the exposure to changes in commodity prices (4).

$$
\mathrm{P}=N_{\text {cur }} * \mathrm{a},(4)
$$

where:

$P$ - valuation of risk;

$N_{c u r}$ - position enterprise-specific foreign currency CUR;

$a$ - possible adverse change in the value of foreign currency, expressed as a decimal fraction.

Additional condition that the decision to hedge currency risks, in addition to having the net position $(\mathrm{N})$ for any foreign currency other than 0 should be a fulfillment of the condition (2), ie valuation of the currency risk should be higher than the costs of hedging.

Possible methods of hedging currency risks the automotive industry are presented in Table 1 . 
Table 1. Methods of currency hedging by the automotive industry, depending on the net position

\begin{tabular}{|c|c|c|c|}
\hline $\begin{array}{l}\text { Method of } \\
\text { hedging }\end{array}$ & $\begin{array}{l}\text { Currency risks on import } \\
\text { operations }(\mathrm{N}<0)\end{array}$ & $\begin{array}{l}\text { Currency risks on export } \\
\text { operations }(\mathrm{N}>0)\end{array}$ & Drawbacks hedging \\
\hline $\begin{array}{l}\text { Forward / } \\
\text { futures hedge }\end{array}$ & $\begin{array}{l}\text { Buy currency forward or } \\
\text { futures contract in foreign } \\
\text { currency in the amount } \\
\text { payable }\end{array}$ & $\begin{array}{l}\text { Sell currency forward or } \\
\text { futures contract in foreign } \\
\text { currency in the amount of the } \\
\text { receivable }\end{array}$ & $\begin{array}{l}\text { Significant losses if the } \\
\text { selected item is incorrect }\end{array}$ \\
\hline $\begin{array}{l}\text { Hedge using } \\
\text { money } \\
\text { market } \\
\text { instruments }\end{array}$ & $\begin{array}{l}\text { Take out a loan in rubles and } \\
\text { convert to currency payables. } \\
\text { Invest the funds in a bank } \\
\text { deposit to the closing of the } \\
\text { transaction. }\end{array}$ & $\begin{array}{l}\text { Take out a loan in foreign } \\
\text { currency receivables and } \\
\text { convert into rubles. Invest the } \\
\text { funds in a bank deposit. Pay } \\
\text { the loan receivable Accounts }\end{array}$ & $\begin{array}{l}t \text { transaction costs } \\
\text { aration }\end{array}$ \\
\hline $\begin{array}{l}\text { Currency } \\
\text { option }\end{array}$ & $\begin{array}{l}\text { Buy currency call option in the } \\
\text { currency and the amount } \\
\text { commensurate payables. }\end{array}$ & $\begin{array}{l}\text { Buy foreign currency put } \\
\text { option (put option) in the } \\
\text { currency and the amount } \\
\text { commensurate receivables }\end{array}$ & $\begin{array}{l}\text { Loss of premium in case of } \\
\text { incorrectly selected item }\end{array}$ \\
\hline $\begin{array}{l}\text { Optional } \\
\text { portfolio }\end{array}$ & $\begin{array}{l}\text { The simultaneous purchase } \\
\text { and sale of a set of call and put } \\
\text { options. }\end{array}$ & $\begin{array}{l}\text { The simultaneous purchase } \\
\text { and sale of a set of call and put } \\
\text { options }\end{array}$ & $\begin{array}{l}\text { Significant losses if the } \\
\text { option portfolio is generated } \\
\text { is not correct }\end{array}$ \\
\hline
\end{tabular}

Thus, the most effective method of hedging for the automotive industry in terms of the risk of possible losses and transaction costs for operations is the buying and selling of foreign currency call and put options on foreign currencies or futures contracts on the currency.

Purchase and sale of options can be carried out through the organization, provide brokerage services on an international exchange LSE or derivatives section of RTS - FORTS and MICEX. The choice of a particular site will depend on the currency, the net position in which it will be necessary to hedge and the size of the commission for the transaction.

When hedge commodity and currency risks is relevant to determine the optimal moment of inception of the hedge - the entry into the market, ie position opening or the date of purchase of option contracts. Implementation of hedging unfavorable points - the points of fracture of the market may lead to a loss of premium paid for the option and not the objective of the hedge.

To solve this problem, it must be assumed that any financial and commodity markets may be three possible types of price movement - rising prices (bullish trend), the price decline (bearish trend) and price fluctuations in the level of achieved values (sideways).

Based on the above to determine the current market situation and future forecast price movements are encouraged to use the following procedure.

On the basis of historical data on the movement of prices is necessary to build a line of Thomas Demark five highest and lowest values of asset prices over a period of 21 days, which corresponds to the market cycle in 4 working weeks;

Calculation of the indicator - the time of price changes (Rate Of Change - ROC) (5).

$$
\mathrm{ROC}=\mathrm{P}_{\text {now }} / \mathrm{P}_{\mathrm{t}} * 100-100,(5)
$$

where:

$\mathrm{P}_{\text {now }}$ - current price

$P_{t}$ - the price of an asset $t$ days ago (proposed to use $t=21$ days, which corresponds to the length of the four-market cycle).

Forecast growth of asset prices will be formed, if the angles of the lines of Thomas Demark respect to the axis of the time period will be in the range [0;90], and the indicator value ROC will be in the range $[10 ;+\infty)$.

The forecast reduction in the price of the asset will be formed if the angles of the lines of Thomas Demark respect to the axis of the time period will be in the range $[90 ; 180]$, and the indicator value ROC will be in the range $(-\infty ;-10]$. 
Forecast the volatility of asset values at the level achieved will be formed if the angles of the lines of Thomas Demark respect to the axis of the time period will correspond to $0 \%$, and the value of the index ROC is in the range $[-10,10]$.

Depending on the forecast changes in asset prices suggest the following sequence of actions to implement the hedge increased cost of raw materials (steel) and currency risks.

Table 2. Selection of strategies hedge changes in raw material prices (steel) and the currency, depending on the dynamics of the foreign exchange and commodity markets for the automotive industry

\begin{tabular}{|c|c|c|}
\hline Forecast changes in asset prices & $\begin{array}{l}\text { Hedging commodity risk (risk of price } \\
\text { increases on steel) }\end{array}$ & Currency risks \\
\hline $\begin{array}{l}\text { Forecast growth in asset prices } \\
\text { (bull trend) }\end{array}$ & $\begin{array}{l}\text { Buying call options on the raw material } \\
\text { (steel) or number of options on futures } \\
\text { contracts for raw materials (steel) }\end{array}$ & $\begin{array}{l}\text { Buying call options on } \\
\text { currency at which the net } \\
\text { position } N_{c u r}<0\end{array}$ \\
\hline $\begin{array}{l}\text { Forecast declines in asset prices } \\
\text { (bearish) }\end{array}$ & wait and see & $\begin{array}{l}\text { Buying put options on } \\
\text { currencies to which the net } \\
\text { position } N_{c u r}>0\end{array}$ \\
\hline
\end{tabular}

Forecast the volatility of the

asset at the level of achieved wait and see attitude wait and see attitude

values (sideways)

Model for the formation of option portfolios for the automotive industry, which is presented below, while minimizing the costs and financial risks, as well as to implement speculative and investment strategies in the automotive industry in the stock market.

Model formed to create options for the purchase of products in the commodity market of steel, but can be the basis for the purchase of foreign currency and other types of metal.

Consider the situation where the automotive industry has access to the stock options market of the London Metal Exchange, where deals are futures and options with different expiration dates.

On the stock market London Metal Exchange traded stock options: call options on futures on steel $S_{c}$ with 2 different strike prices (prices expiry options) and put options $S_{p}$ also with 2 (3 months and 15 months) with different strike prices.

We presume that in any market there are three possible options for forecasting price movements relative to the total - an increase, decrease and sideways.

Automotive industry to strive to get maximum results in the event that the price of the underlying asset at some point in the future will take a certain predicted value or one of the predicted values, but set loss limits adverse price movement.

Futures have as underlying asset prices for steel and options - futures steel.

We denote the possible values of the futures price set of $P_{E}[0 ;+\infty]$. An investor can expect different behavior of prices of the underlying asset from the current $P_{\text {now }}$. Forecasts investor can be written as follows:

- Normal growth forecast or fall in the price of the underlying asset to a certain value in a target point $P_{E}=$ $P_{\text {Expected }}$, which is the point of intersection of two moving averages: short and long. Depending on whether the $P_{E}>P_{\text {now }}$ or $P_{E}<P_{\text {now }}$, this price forecast will be talking about the expected growth potential or falling asset prices;

- Bimodal forecast price changes of the underlying asset to the first or second $P_{E 1}, P_{E 2}$ target prices where $P_{E 1}<P_{E 2}$ and ROC is in the range [-10,10], and the line of Thomas De Mark parallel.

Depending on the position of target prices $P_{E 1}$ and $P_{E 2}$ relatively $P_{\text {now }}$ this forecast can talk about the strong/ moderate increase price volatility of the underlying asset or the expected upside / downside to the two possible target prices of the underlying asset.

\section{Conclusions}

Thus, instruments to build complex option products under a given set of traded contracts, to minimize costs and risks, achieving the purpose of the enterprise, developing investment and speculative strategies. The proposed 
methods of hedging currency risks by the automotive industry as a function of net positions and the choice of strategies hedge the exposure to changes in commodity prices and currency, depending on the dynamics of the currency and commodity markets can be used by both Russian and foreign automotive industry.

\section{References}

Abdreev, T. I., \& Tufetulov, A. M. (2014). Legal status of an appraiser in the Russian Federation under globalization. Mediterranean Journal of Social Sciences, 5(24), 188-192. http://dx.doi.org/10.5901/mjss. 2014.v5n24p188

Berk, A. S., \& Loncarski, I. (2011). Are exogenous requirements sufficient to induce corporate risk management activities? Post-Communist Economies, 23(1), 119-137. http://dx.doi.org/10.1080/14631377.2011.546994

Garifova, L. F. (2014). Tendencies of small business development in the Russian information economy. Mediterranean Journal of Social Sciences, 5(24), 336-340. http://dx.doi.org/10.5901/mjss.2014.v5n24p336

Jurše, M., Logožar, K., Ključevšek, M., \& Korez-Vide, R. (2011). Diagonal cumulation of origin as an institutional incentive mechanism for cost optimization in contemporary international business. Acta Economica, 61(2), 165-191. http://dx.doi.org/10.1556/AOecon.61.2011.2.4

Kong, D., Tiong, R. L. K., Cheah, C. Y. J., Permana, A., \& Ehrlich, M. (2008). Assessment of credit risk in project finance. Journal of Construction Engineering and Management, 134(11), 876-884. http://dx.doi.org/10.1061/(ASCE)0733-9364(2008)134:11(876)

Lin, S.-Y., Chuang, H.-M., \& Shyu, D. (2009). Time-Varying risk premia, heterogeneous investors and the dynamics of exchange rate and stock returns. International Research Journal of Finance and Economics, $1(28), 120-133$.

Marion, T. J., \& Meyer, M. (2011). Applying industrial design and cost engineering to new product development in early-stage firms. Journal of Product Innovation Management, 28(5), 773-786. http://dx.doi.org/10.1111/ j.1540-5885.2011.00839.x

Matiş, D., Strouhal, J., \& Bonaci, C. G. (2009). Regulators and regulations for financial instruments in the context of financial crisis 'to emerging countries'. Research in Accounting in Emerging Economies, 9, 345-377. http://dx.doi.org/10.1108/S1479-3563(2009)0000009015

Pavlidis, E. G., Paya, I., \& Peel, D. A. (2011). Real exchange rates and time-varying trade costs. Journal of International Money and Finance, 30(6), 1157-1179. http://dx.doi.org/10.1016/j.jimonfin.2011.06.004

Valitov, S. M., \& Nigmetzyanov, A. A. (2014). New requirements of the basel committeee on banking supervision to capital as a measure to ensure the stability of the banking sector. Mediterranean Journal of Social Sciences, 5(24), 294-299. http://dx.doi.org/10.5901/mjss.2014.v5n24p294

Zhang, H. (2009). Effect of derivative accounting rules on corporate risk-management behavior. Journal of Accounting and Economics, 47(3), 244-264. http://dx.doi.org/10.1016/j.jacceco.2008.11.007

\section{Copyrights}

Copyright for this article is retained by the author(s), with first publication rights granted to the journal.

This is an open-access article distributed under the terms and conditions of the Creative Commons Attribution license (http://creativecommons.org/licenses/by/3.0/). 